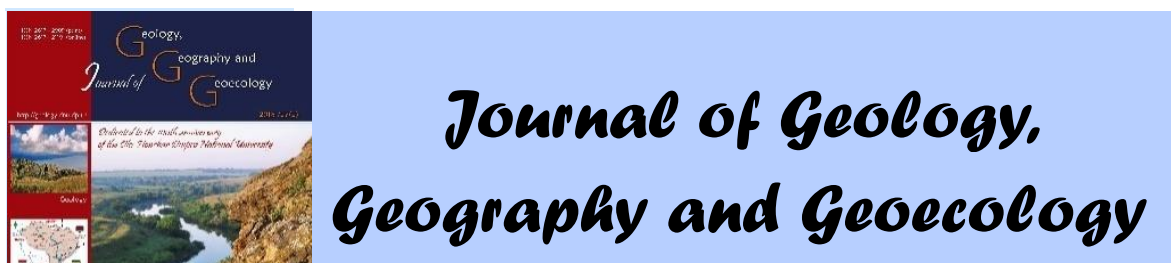

Journal home page: geology-dnu-dp.ua
Journ.Geol.Geograph.

Geoecology, 28(1), 188-198 doi: $10.15421 / 111920$

O. Suhina, S. Shults, V. Tkach,

N. Popadynets, O. Kamushkov

Journ.Geol.Geograph.Geoecology, 28(1), 188-198

\title{
Methodology of evaluating economic losses resulting from partial loss of the air ecosystem's assimilative capacity
}

\author{
O. Suhina ${ }^{1}$, S. Shults ${ }^{2}$, V. Tkach ${ }^{3}$, N. Popadynets ${ }^{2}$, O. Kamushkov ${ }^{4}$ \\ ${ }^{1}$ State Institution "Institute of Environmental Economics and Sustainable Development of NAS of Ukraine ", Kyiv, \\ Ukraine, e-mail: olsuhina@ukr.net \\ ${ }^{2}$ State Institution "Institute of Regional Research named after M. I. Dolishniy of NAS of Ukraine", Lviv, Ukraine \\ ${ }^{3}$ Alfred Nobel University, Dnipro, Ukraine \\ ${ }^{4}$ Khortytsya National Academy, Zaporizhzhia, Ukraine
}

Received 17.12.2018;

Received in revised form 24.01.2019;

Accepted 12.03.2019

Abstract. Nowadays the ecosystem approach is widely applied in many countries globally to evaluate economic losses from pollution of the natural environment. In Ukraine, it is reasonable to develop both the methodology of evaluation of economic losses from pollution of the natural environment and the methodology of calculation of correlating coefficients of ecosystems' assimilative properties for differentiation of the volumes of repayment of economic losses from pollution of nature. The following methods were used in the research: economic and mathematical modeling - for formalization of the evaluation of economic losses from partial loss of the air ecosystem's assimilative capacity; synthesis and analysis, system approach - for analysis of existing mathematical models, evaluation of economic losses from air pollution and forming of institutional environment of calculation of economic losses from partial loss of the air ecosystem's assimilative capacity; inductive - for making conclusions over the best methodological approach to be used for calculation of oxygen production costs. The condition of the institutional environment is analyzed, including the regulatory and organizational maintenance of evaluation of economic losses from air pollution. The paper proves that the existing relevant institutional environment is partially coordinated with international formal rules and organizational structures, which evaluate such economic losses; however, their further efficient evaluation requires timely transformation based on the ecosystem approach to EU directives. The recommendations regarding the institutionalization of the process of ecosystem calculation of caused and prevented losses from the partial loss of the air ecosystem's assimilative capacity are suggested: application of 2008/50/EU Directive of European Parliament and Council as of May 21, 2008 on Ambient Air Quality and Cleaner Air for Europe; review of the amounts of harmful substances TLV in the air; the need to take into account certain factors while calculating economic losses from air pollution (including the calculation of damage to life and health of each person due to air pollution), approval of the documents already developed and adopted but suspended by the Ministry of Justice of Ukraine, etc. New methodological approaches to alternative evaluation of economic losses from partial loss of the air ecosystem's assimilative capacity as opposed to the current one are suggested, including methodological approaches to calculation of the oxygen and nitrogen production costs on the basis of the carbon offsets realization; methodological approaches to calculation of the oxygen production costs based on installation of artificial photosynthesis; methodological approaches to calculation of the oxygen production costs based on natural photosynthesis - planting and conservation of forests; methodological approaches to calculation of the oxygen and nitrogen "production" costs in metallurgical production; methodological approaches to calculation of prevented economic losses from partial loss of the air ecosystem's assimilative capacity, which are manifested in the long run or those of indirect nature.

Keywords: assimilative properties of the air ecosystem, atmospheric air, soils, institutional environment, economic losses from pollution, forest resources, methodological approaches.

\section{Методологія оцінки економічних збитків від часткової втрати асиміляційної здатності повітряної екосистеми}

\author{
О. Сухіна ${ }^{1}$, С. Шульц ${ }^{2}$ В. Ткач ${ }^{3}$, Н. Попадинець ${ }^{2}$, О. Камушков ${ }^{4}$
}

${ }^{1}$ ДУ «Інститут економіки природокористування та сталого розвитку НАН України», м. Київ, Україна е-таіl: olsuhina@ukr.net

${ }^{2} Д У$ «нститут регіональних досліджень імені М. І. Долішнього НАН України», Львів, Украӥна

${ }^{3}$ Університет імені Альфреда Нобеля, м. Дніпро, Україна 
${ }^{4}$ КВНЗ «Хортищьька національна навчально-реабілітаційна академія» Запорізької обласної ради, м. Запоріжжя, Україна

\begin{abstract}
Анотація. Проаналізовано інституціональне середовища, що включає нормативно-законодавче та організаційне забезпечення оцінки економічних збитків від забруднення атмосферного повітря. Встановлено, що наявне інституційне середовище частково координується 3 міжнародними формальними правилами і організаційними структурами, що здійснюють оцінку економічних збитків. Розроблено пропозиції до інституціоналізації процесу екосистемного визначення заподіяних та попереджених збитків від часткової втрати асиміляційної здатності повітряної екосистеми. Здійснено аналіз впливу атмосферних забруднень на стан навколишнього природного середовища, що проявляється в підвищенні захворюваності населення, негативних наслідках забруднення водних ресурсів та грунтів атмосферними випаданнями, зниженні біопродуктивності екосистем, передчасному зносі основних фондів і покриттів, інших втрат, що не все враховується чинною методикою розрахунку розмірів відшкодування збитків, які заподіяні державі в результаті наднормативних викидів забруднюючих речовин в атмосферне повітря. Розроблено методологічні підходи до визначення розмірів заподіяних економічних збитків від часткової втрати асиміляційної здатності повітряної екосистеми, які базуються на нормативному та покомпонентному підходах, а також фіксованих величин, встановлених законодавчо, а не реальних витрат на усунення наслідків економічних збитків від забруднення атмосферного повітря, зокрема: методологічні підходи до розрахунку вартості виробництва кисню та азоту на базі реалізації вуглецевих квот; методологічні підходи до визначення вартості виробництва кисню за допомогою установки штучного фотосинтезу; методологічні підходи до розрахунків вартості виробництва кисню за допомогою природного фотосинтезу - насадження та збереження лісів; методологічні підходи до розрахунків вартості “виробництва" кисню й азоту при металургійному виробництві; методичні підходи до визначення розмірів попереджених, які мають віддалені у часі прояви або мають опосередкований характер, економічних збитків від втрати асиміляційної здатності повітряної екосистеми.
\end{abstract}

Ключові слова: асиміляційні властивості повітряної екосистеми, атмосферне повітря, трунти, інституційне середовище, економічні збитки від забруднення, лісові ресурси, методологічні підходи.

Introduction. Nowadays it is rather problematic to evaluate economic losses from pollution or degradation of the ecosystem of any territory, therefore application of the ecosystem approach is of the utmost importance. The approach should include the following components: atmospheric air, water and land resources, flora and fauna, etc. If, for example, due to fire the condition of atmospheric air deteriorates not only in a certain ecosystem, but also in the territory of other countries, i.e. the crossborder pollution, other methodological approaches are needed. There can be no universal methodology to evaluate economic losses from the negative influence on the environment (land and water resources, atmospheric air) since some enterprises pollute the atmosphere and others - only the water in rivers. The differentiation in evaluation of losses provides the necessary effect. The current Methodology of Calculation of Compensation for Losses Inflicted on Nature of the State due to Excessive Emissions of Pollutants into the Atmospheric Air (Ministry of Environmental Protection of Ukraine, 2008) is biased and does not take into consideration the ecosystem approach, remote expenditures and evaluation of losses inflicted upon the life and health of each person due to pollution of atmospheric air, increased morbidity rate, negative consequences of pollution of water resources and soils by precipitations and reduction of ecosystems' bioproductivity.

The question of approaches to evaluation of losses from pollution of the environment is outlined in the research of domestic and foreign scientists (Davydova, 2018; Emerton, 2003; Kvashyn et al.,
2013; Lakyda, 2011; Lobasov, 2013; Matyukha, 2016; Mayer et al., 2012; Maksymiv, 2016; Meng, 2015; Razovskyi, 2017; Tagaeva, 2015). The detailed analysis of methodology of evaluation of losses from environmental pollution taking into account the ecosystem approach abroad was conducted by (Balatsky, 2007; Boldyrev, 2001; Yazhlev, 2009). However, despite a great amount of research, the evaluation of the loss of the air ecosystem's assimilative capacity remains underdeveloped.

The paper aims to develop methodological approaches to evaluation of economic losses from partial deprivation of the air ecosystem's assimilative capacity taking into account the institutional aspects.

Material and methods of research. The following general scientific methods were applied to perform the research: economic and mathematical modeling - to formalize the evaluation of economic losses from partial deprivation of the air ecosystem's assimilative capacity (with representation of the authors' mathematical formulas);

methods of synthesis, analysis, induction, deduction and system approach - to process the received materials and foreign experience and to analyze existing mathematical models that evaluate economic losses from air pollution and to form an institutional environment of evaluation of economic losses from partial deprivation of the air ecosystem's assimilative capacity, including the comparative analysis method - to calculate the cost of oxygen production over a period of years; 
inductive method - to develop conclusions on which method should be used to calculate the cost of oxygen production;

analysis method - to prove that the current Methodology of Calculation of Compensation For Losses Inflicted on Nature of the State due to Excessive Emissions of Pollutants into the Atmospheric Air (Ministry of Environmental Protection of Ukraine, 2008) is biased and does not consider the ecosystem approach, etc;

as well as specific ones, in particular the method "all things being equal" - to calculate optimal cost of oxygen and nitrogen production based on installation of artificial photosynthesis (Suhina, 2018) and to develop methodological approaches to calculation of oxygen and nitrogen "production" in metallurgy and calculation of oxygen production costs to be compared to those outlined in the research.

Results and their analysis. Analysis of existing mathematical models to evaluate economic losses from environmental pollution shows that certain scientific capacity in the sphere is already created and is further displayed both in scientific works and in regulations. The situation abroad is like this: "Most of evaluations of losses from $1 \mathrm{t}$ of $\mathrm{CO}_{2}$ are within $\$ 10.0-100.0$ or $\$ 0.03-0.3$ per gallon of gasoline. Evaluation of losses calculated based on American data exceeds dozens or even hundreds thousands times the Ukrainian evaluations" (Melnyk, 2004).

Unfortunately, Ukrainian legislation in the sphere of guaranteeing the ecological security and introduction of efficient ecological policy falls short of the requirements of EU Directives. Harmonization of Ukrainian laws with EU legislation is mentioned in the Chapter "Environmental governance and integration of environment into other policy areas" of Annex XXX to Chapter 6 "Environment" of Title V "Economic and Sector Cooperation" of Association Agreement between Ukraine, on the one hand, and the European Union, the European Atomic Energy Community and their Member States, on the other hand (2014). However, the ecosystem approach is not applied properly in Ukraine and no measures to prevent losses are taken. Regarding the institutional provision of evaluation of economic losses from air pollution, it is worth mentioning that it is necessary that the Ministry of Justice of Ukraine approves the regulations already developed and adopted but currently suspended. For example, "State sanitary rules of protection atmospheric air of settlements (from chemical and biological pollutants) (SSR201-97)" - Decree of the Ministry of Healthcare of Ukraine as of 9 July 1997, № 201 wasn’t registered by the Ministry of Justice of Ukraine and was terminated as of 7 August 2014 (Ministry of Healthcare of Ukraine, 1997).

While calculating the losses from environmental pollution it is necessary to use the procedure on protection of atmospheric air of settlements indicated in the Decree of the Ministry of Healthcare of Ukraine as of 19 June 1996, № 173 "On Approval of State Sanitary Rules of Settlements' Planning and Development" (Ministry of Healthcare of Ukraine, 1996)

Therefore, institutionalization of the process of ecosystem-based calculation of inflicted and prevented losses from partial deprivation of the air ecosystem's assimilative capacity can include the following legal and economic instruments:

- application of provisions of the Directive 2008/50/EC of the European Parliament and of the Council of 21 May 2008 on Ambient Air Quality and Cleaner Air for Europe (Directive of European Parliament and Council, 2008) and other regulations;

- development of recommendations to apply the ecosystem approach in the course of elaboration of methodological approaches to evaluation of economic losses from atmospheric air pollution;

- development of recommendations to consider certain factors in evaluation of economic losses from atmospheric air pollution (including calculation of damages to life and health of each person due to atmospheric air pollution).

- review of the volumes of average daily concentration limit (hereinafter-CL) of atmospheric air pollutants (Ministry of Environmental Protection of Ukraine, 2006; Cabinet of Ministers of Ukraine, 2001), etc;

- development of methodological approaches to calculation of the oxygen and nitrogen production costs based on realization of carbon offsets;

- development of methodological approaches to calculation of the oxygen production costs based on installation of artificial photosynthesis;

- development of methodological approaches to calculation of the oxygen production costs based on natural photosynthesis - developing and keeping of forests;

- development of methodological approaches to calculation of the oxygen and nitrogen "production" costs in metallurgy;

- development of methodological approaches to calculation of prevented economic losses from the deterioration of the air ecosystem's assimilative capacity, visible in time and of indirect nature; 
- adoption of already developed and approved but currently suspended regulations by the Ministry of Justice of Ukraine, etc.

It is reasonable to take into account not only direct losses emerging in separate periods of time (healthcare costs. etc), but also the remote ones, i.e. those that can emerge in future due to illnesses or health deprivation (additional losses due to reduced work capacities in future, etc).

It is necessary to calculate losses caused to the territory and life and health of each person due to atmospheric air pollution.

As for now, we have developed methodological approaches to evaluation of economic losses from partial loss of the air ecosystem's assimilative capacity, which is alternative to the existing one, in particular: methodological approaches to calculation of oxygen and nitrogen production cost based on realization of carbon offsets; methodological approaches to calculation of the oxygen production costs based on installation of artificial photosynthesis; methodological approaches to calculation of the oxygen production costs based on natural photosynthesis - developing and preservation of forests; methodological approaches to calculation of the oxygen and nitrogen "production" costs in metallurgy and methodological approaches to calculation of prevented economic losses from the loss of the air ecosystem's assimilative capacity, visible in time and of indirect nature.

Methodological approaches to calculation of oxygen and nitrogen production cost based on realization of carbon offsets and the calculation itself.

For each type of "work" of nature's (an ecosystem's) assimilative capacity, it is reasonable to form concrete methodological approaches to evaluation of its value in terms of neutralization of pollutants. The technologies (waste management, water purification and desalination, atmospheric air purification, etc) are constantly being improved and becoming cheaper. For example, there is a shortage of fresh water in Israel, therefore the seawater is desalinated for economic needs. The cost of "work" of assimilative capacity of water, forests and air should be evaluated based on a new combination of parameters of complex, synergy type, which should be applied in the process of differentiation of rentals for the use of ecosystems' assimilative services.

V.M. Boldyrev (Boldyrev, 2001) deems it necessary to establish quotas not for anthropogenic $\mathrm{CO}_{2}$ emissions, bur rather for anthropogenic consumption of atmospheric oxygen. The approach can become the foundation of the Paris Agreement on Climate Change. The USA and
Russia have developed regulations on taxes on air. In due time, in the Kyoto Protocol the countries established the rate of $\$ 10$ per each ton of $\mathrm{CO}_{2}$ absorbed by "green lungs" of a certain country above its emission limit (the cost ranged, at times it amounted to \$3). When hydrocarbon fuel burns, the atmospheric oxygen is also spent on water production. After plants have absorbed the whole carbon dioxide from hydrocarbon fuel combustion, they do not restore the initial content of oxygen in the atmosphere. If industrially developed countries are ready to pay $\$ 10$ per one ton of "extra" $\mathrm{CO}_{2}$ emission and as far as 0.727 tons of oxygen emerge due to decomposition of one ton of carbon dioxide, then possibly $\$ 13.8(10 / 0.727)$ is the reasonable cost of plants' production of one ton of atmospheric air.

The main components of dry air are nitrogen $(78.09 \%)$ and oxygen $(20.95 \%)$, as well as small volumes of carbon dioxide, hydrogen and other gases. In this case, we take into account oxygen and nitrogen.

We suggest calculation of the cost of their production based on realization of carbon offsets by the formula:

$$
\mathrm{C}_{\mathrm{o}}=\frac{C_{c o_{2}}}{0,727}
$$

where: $\mathrm{C}_{0}$ - oxygen cost, UAH/t;

$\mathrm{C}_{\mathrm{CO}_{2}}-$ cost of "extra" carbon dioxide on the carbon market (cost of carbon offsets), UAH/t.

\section{Calculation sample.}

Cost of carbon offsets. In May 2018 at the Innovate4Climate Forum in Frankfurt, the World Bank and the International Emissions Trading Association (IETA) announced that currently more than the half of all emission under "carbon" mechanisms is traded at over $\$ 10.0$ per ton of $\mathrm{CO}_{2-}$ equivalent (in 2017 - only the quarter). The experts expect the further growth of prices within the European Trade System (ETS) - up to $€ 22.0$ after 2021. Nowadays, the price of a ton of $\mathrm{CO}_{2}$ within the ETS amounts approximately to $€ 15$. The experts of the International Emissions Trading Association (IETA) think that in order to achieve the goals of the Paris Agreement (constraining the global temperature growth within $2^{\circ} \mathrm{C}$ ) an average price for 1 ton of $\mathrm{CO}_{2}$ should be no less than $€ 50.0$. Therefore, they emphasize that governments should take more measures in the sphere of greenhouse gas reduction (Davydova, 2018).

Cost of oxygen and nitrogen. Calculations are done based on data as of 1 August 2018, when \$ 
1 was worth 27.01 UAH. The cost of carbon dioxide emission quota was $\$ 10.0$. (I scenario), \$ 3.0 (II) and \$20.0 (III scenario). However, the data of V.M. Boldyrev are related to extra emissions, so in calculations we should take lower rates.

1 scenario. According to the formula (1) (carbon dioxide cost $-\$ 10.0$ ), oxygen cost is UAH $372.6 / \mathrm{t}(\$ 13.8 / \mathrm{t})$.

With $0.001429 \mathrm{t}$ of gaseous oxygen in 1 cubic meter, the $\operatorname{cost}^{1}$ of a cubic meter of oxygen amounts to $\$ 0.0197202 / \mathrm{m}^{3}$ (UAH $0.5324454 / \mathrm{m}^{3}$ (the cost of nitrogen in calculations will be about the same): cost of $0.0017 \mathrm{~m}^{3}$ of air (oxygen and nitrogen) for dilution of $1 \mathrm{mg}$ of $\mathrm{CO}_{2}$ with $589 \mathrm{mg} / \mathrm{m}^{3}$ $\mathrm{CO}_{2}$ concentration (Kvashyn, 2008) in the air will be $\$ 0.00003352434$ (UAH 0.00090515718 ).

2 scenario. According to the formula (1) (carbon dioxide cost $-\$ 3.0$ ), oxygen cost is UAH $110.7 / \mathrm{t}(\$ 4.1 / \mathrm{t})$.

With $0.001429 \mathrm{t}$ of gaseous oxygen in 1 cubic meter, the cost of a cubic meter of oxygen amounts to $\$ 0.0058589$ (UAH $0.1581903 / \mathrm{m}^{3}$ ) (the cost of nitrogen in calculations is about the same): cost of $0.0017 \mathrm{~m}^{3}$ of air (oxygen and nitrogen) for dilution of $1 \mathrm{mg}$ of $\mathrm{CO}_{2}$ with $589 \mathrm{mg} / \mathrm{m}^{3} \mathrm{CO}_{2}$ concentration in the air is $\$ 0.00000996013$ (0.00026892351 UAH).

3 scenario. According to the formula (1) (carbon dioxide cost $-\$ 20.0$ ), oxygen cost is UAH $742,5 / \mathrm{t}(\$ 27,5 / \mathrm{t})$.

With $0.001429 \mathrm{t}$ of gaseous oxygen in 1 cubic meter, the cost of a cubic meter of oxygen amounts to $\$ 0.0392975\left(\mathrm{UAH} 1.0610325 / \mathrm{m}^{3}\right.$ ) (the cost of nitrogen in calculations is about the same): cost of $0.0017 \mathrm{~m}^{3}$ of air (oxygen and nitrogen) for dilution of $1 \mathrm{mg}$ of $\mathrm{CO}_{2}$ with $589 \mathrm{mg} / \mathrm{m}^{3} \mathrm{CO}_{2}$ concentration in the air is $\$ 0.00006680575(\mathrm{UAH}$ 0.00180375525).

According to the World Bank, as of 2016, the carbon tax per one ton of $\mathrm{CO}_{2}$ was established in the following countries: Denmark (\$ 31.0), Finland ( $€$ 35.0), France ( $€ 7.0)$, Iceland (\$10.0), Ireland ( $€$ 20.0), Norway (\$4.0-69.0), Sweden (\$ 168.0), Switzerland (\$ 68.0), and Great Britain (\$ 15.75).

The European Commission has developed a long-term strategic program called 2050 Energy Roadmap with the major objective of massively introducing technologies of carbon capture and storage for 2030-2050. According to various data, the capture and storage cost of $1 \mathrm{t}$ of $\mathrm{CO}_{2}$ will be $€$ 40.0 to 400.0). As far as the companies are better off paying, for example, $€ 17.0$ for $\mathrm{CO}_{2}$ emission rather than $€ 400.0$ for its utilization, the framework

\footnotetext{
${ }^{1}$ In $1 \mathrm{~m}^{3}-0.001429 \mathrm{t}$ of gaseous oxygen with barometric pressure $760 \mathrm{~mm} \mathrm{Hg}$ and $\mathrm{t} 0^{\circ} \mathrm{C}$.
}

of this strategic program suggests the increase of tariffs in order to raise interest in the technologies of carbon dioxide storage: by 2020 the charge on $\mathrm{CO}_{2}$ emissions will be in average $€ 38.0 / \mathrm{t}$, and by $2030-€ 85.0 / \mathrm{t}$. While in developed countries the charge on carbon dioxide emissions and its utilization are about to grow up to hundreds of euros, in Ukraine the rate has increased only by 2 kopecks in the last couple of years (from 24 to 26 kopecks/t in 2014). According to Art. 243.4 of the Tax Code of Ukraine, as of 1 August 2018, the charge on carbon dioxide emissions was UAH 0.41 per 1 ton.

In Norway the charge on carbon dioxide emissions was almost $€ 40 / \mathrm{t}$ already back in 2008 . However, the oil \& gas company «Statoil Hydro» claimed that even with this charge they are better off emitting $\mathrm{CO}_{2}$ into the atmosphere rather than injecting it into the strata.

In 2016 an article on construction of the world's first commercial plant for capturing carbon dioxide from air in Zurich by the Swiss company Climeworks was published (almost 2-3 tons of carbon dioxide daily) (Cryogen, 2016). Afterwards, it was planned to be sold to agricultural producers. Nowadays the cost of one ton of $\mathrm{CO}_{2}$ amounts to $\$$ 600.0 thousand. Climeworks claims to reduce the price to make the DAC technology cost-effective. The direct air capture technology (DAC) stipulates the use of fibrous sponge-like filter material that has been impregnated with chemicals called amines. Amines derive from ammonia, which bind to $\mathrm{CO}_{2}$. The filtered air is cleaned up from carbon dioxide. The method of direct air capturing and purification is used in submarines and the ISS (International Space Station).

\section{Methodological approaches to calculation of oxygen production cost based on installation of artificial photosynthesis.}

The developers of the system of artificial photosynthesis to initiate chemical reaction suggest the use of a device, similar to a solar panel in its functions and materials. Therefore, in order to calculate the cost of oxygen production we have to find out the cost of artificial photosynthesis installation (including the cost of necessary solar panels), its servicing and water. Carbon dioxide from atmosphere is a free of charge natural raw material.

\section{Calculation sample.}

It is applicable in cases when artificial photosynthesis installations produce fuel and oxygen is only a by-product and is cheap (e.g. $3.375 \mathrm{kopecks} / \mathrm{m}^{3}$ or less). Indeed, the cost of a synthetic engine oil production in the Russian Federation with alternative installation "AIST" 
("AIST - alternative sources of synthetic fuel") by TOV "NVO "Bazalt" (carbon-containing wastes processing company in Tomsk) is 3.24 kopecks/liter in Ukrainian currency (200 litres per hour). Therefore, the production of one liter of fuel costs less than 3.375 kopecks. In such conditions, the cost of oxygen production can be much less, taking into account the fact that oxygen will be the by-product of hydrogen fuel production (possibly 0.3375 kopecks $/ \mathrm{m}^{3}$ ).

Calculations of oxygen production cost by this method. Given the UAH $0.03375 / \mathrm{m}^{3}$ (3.375 kopecks $/ \mathrm{m}^{3}$ ) cost of oxygen and nitrogen production - major air components - in August 2018:

- cost of $20 \mathrm{~m}^{3}$ of air for dilution of $1 \mathrm{mg}$ of $\mathrm{SO}_{2}$ with $0.05 \mathrm{mg} / \mathrm{m}^{3} \mathrm{CL}$ (average daily) (Ministry of Healthcare of Ukraine,1997) ${ }^{2}$ - UAH 0.675;

- cost of $0.0017 \mathrm{~m}^{3}$ of air for dilution of $1 \mathrm{mg}$ of $\mathrm{CO}_{2}$ with $589 \mathrm{mg} / \mathrm{m}^{3} \mathrm{CO}_{2}$ concentration in air UAH 0.000057375 .

By this method, we can calculate the cost of oxygen for dilution of each pollutant applying the $\mathrm{CL}$ rates.

If oxygen production cost is $\mathrm{UAH}$ $0.03375 / \mathrm{m}^{3} \quad\left(3.375 \mathrm{kopecks} / \mathrm{m}^{3}\right)$, then one $\mathrm{t}$ of oxygen is UAH 23.61825 (i.e. 15.8 times less than suggested by V.M. Boldyrev by oxygen quotas UAH 372.6/t (\$ 13.8/t).

Methodological approaches to calculation of oxygen production cost based on natural photosynthesis - development and preservation of forests.

Oxygen production cost based on natural photosynthesis is calculated by the formula:

$$
\mathrm{C}_{\mathrm{oc}}=C_{d k f}
$$

where: $\mathrm{C}_{\mathrm{oc}}-$ cost of oxygen production based on natural photosynthesis, UAH;

$C_{d k f}-$ cost of developing and protecting forests from pests, UAH.

Cost of production of $1 \mathrm{t}$ of oxygen based on natural photosynthesis is calculated by the formula:

$$
C_{\mathrm{pl}_{\mathrm{t}} \mathrm{o}}=\frac{C_{d k 1_{h a} f}}{M_{o}}
$$

\footnotetext{
2 According to the Decree of the Ministry of Environmental Protection of Ukraine "On Approval of the Normative of Maximum Permissible Emissions of Pollutants from Stationary Sources" maximum permissible emissions of sulphur dioxide are $500 \mathrm{mg} / \mathrm{m}^{3}$.
}

where: $C_{\mathrm{p}_{\mathrm{t}} \mathrm{o}}-$ cost of production of $1 \mathrm{t}$ of oxygen based on natural photosynthesis, UAH.;

$C_{d k 1_{h a} f}$ - cost of developing and protecting 1ha of forests from pests, UAH.

$M_{o}$ - mass of oxygen produced by plants per 1 ha of forests

Calculation sample.

Each minute 30ha of forests are destroyed on our planet - the green "lungs" of the planet. Each year one percent of forest disappears from the planet Earth.

According to the State Agency of Forest Resources of Ukraine at least UAH 12.0 15.0 thousand. are needed to plant (manually, to plant forest without total ploughing) 1 ha of pine forests and to preserve it. However, one has to wait $80-90$ years before logging (up to 200 years for oak forests), constantly spending significant funds (up to UAH 17.0 thous.) for protecting and protecting the forest from pests or harsh weather. These are substantial funds for the newly created territorial communities.

In 2009, Ukraine adopted the Methodology of Calculation of Green Plantings' Replacement Value (Ministry of Housing of Ukraine, 2009).

The results of Ukrainian scientists' research (I.P. Lakyda et al.) were also used for our calculations (Lakyda, 2011). Oak and pine trees have the strongest oxygen production capacity (6.7t/ha and 4.8-5.9t/ha accordingly). Each year 1 ha of 20-year old pine forests absorbs $9.35 \mathrm{t}$ of carbon dioxide and generates $7.25 \mathrm{t}$ of oxygen and one ha of those 60-year old $-14.4 \mathrm{t}$ and $10.9 \mathrm{t}$. In their turn, 40-year old oak forests absorb $18 \mathrm{t}$ of carbon dioxide and generate 13.9t of oxygen each year. Moreover, artificially developed forests have a lower level of oxygen production. I.P. Lakyda has determined that oxygen production of urban modal artificial pine forests in Kyiv amounts to from 38.2 (age 10 years) to $2,224.6$ (age - 140 years) t/ha by general productivity.

As of July 2018, the cost of preserving and protecting from pests of 1 ha of forests amounted to UAH 17.0 thous. annually (calculations are based not on the cost of land or afforestation, but only on approximate cost of preserving the forest for 1 year).

1ha of pine forests annually generate 4.8 5.9 t/ha $(7.25$ - 20-year old forests; 10.9 - those 60 years old) of oxygen.

$4.8 \mathrm{t} / \mathrm{ha}$ of oxygen generated by pine forest costs UAH 17.0 thous.

Then the cost of one t of oxygen is: UAH 3.54 thous. (UAH 17.0 thous. : $4.8 \mathrm{t}$ of oxygen (as 
far as artificially planted forests generate less oxygen than the natural ones, we use lower rates in our calculations)).

With $0.001429 \mathrm{t}$ of gaseous oxygen in $1 \mathrm{~m}^{3}$, the cost of $1 \mathrm{~m}^{3}$ of oxygen is UAH $5.05866 / \mathrm{m}^{3}$ (in calculations the cost of nitrogen will be about the same);

- cost of $0.0017 \mathrm{~m}^{3}$ of air for dilution of $1 \mathrm{mg}$ of $\mathrm{CO}_{2}$ with $589 \mathrm{mg} / \mathrm{m}^{3} \mathrm{CO}_{2}$ concentration in the air - UAH 0.008599722;

if in this example the cost of one $t$ of oxygen is UAH 3.54 thous, it is 9.5 times more than the cost of one $t$ of oxygen suggested by V.M. Boldyrev (UAH 372.6/t or \$ 13.8/t).

This methodological approach can be applied when assessing the economic losses from atmospheric air pollution.

For comparison. As of July 2013, the cost of preserving and protecting and from pests 1 ha of forests - UAH 5 thous. annually (calculations are based not on the cost of land or afforestation, but only on approximate cost of preserving the forest for 1 year).

1ha of pine forests annually generate 4.8 $5.9 \mathrm{t} / \mathrm{ha}$ (7.25 - 20-year old forests; 10.9 - those 60 years old) of oxygen.

$4.8 \mathrm{t} / \mathrm{ha}$ of oxygen generated by pine forest costs UAH 5 thous.

Then the cost of one $t$ of oxygen is: UAH 1.04 thous. (UAH 5.0 thous. : $4.8 \mathrm{t}$ of oxygen (as far as artificially planted forests generate less oxygen than natural ones, we use lower rates in our calculations)).

With $0.001429 \mathrm{t}$ of gaseous oxygen in $1 \mathrm{~m}^{3}$, the cost of $1 \mathrm{~m}^{3}$ of oxygen is UAH $1.48616 / \mathrm{m}^{3}$ (in calculations the cost of nitrogen will be about the same);

- cost of $0.0017 \mathrm{~m}^{3}$ of air for dilution of $1 \mathrm{mg}$ of $\mathrm{CO}_{2}$ with $589 \mathrm{mg} / \mathrm{m}^{3} \mathrm{CO}_{2}$ concentration in the air - UAH 0.002526472.

Methodological approaches to calculation of the oxygen and nitrogen "production" costs in metallurgy.

The data is provided only as an example, because oxygen is not produced but only concentrated by modern generators - high-speed turbo expanders (nitrogen is replaced by oxygen). Nitrogen is forced out using concentrators at low temperatures $\left(-182.9^{\circ} \mathrm{C}\right)$ through rectification. According to state technical standard 5583-78, oxygen varies by the degree of purity (99.799.2\%). However, harmful substances dissolve in nitrogen, the cost of production (concentration) of which is about the same. Oxygen is essential not only for intensification of chemical and metallurgical processes (steelmaking, welding); it is often used for maintaining the functioning of living organisms (emergency oxygen supply in bomb shelters (in cylinders) and in submarines, medical gaseous oxygen for breathing and therapeutic purposes). That is why it is generated using highperformance turbochargers and expanders, which are correspondingly expensive. Electric energy consumption for obtaining of $1 \mathrm{~m}^{3}$ of industrial pure oxygen $\mathrm{O}_{2}$ is $0.4-1.6 \mathrm{kWh}$ (depending on the installation type) or up to $4.1 \mathrm{kWh}$ per $1 \mathrm{~kg}$ of liquefied air with the pressure in compressor $200 \mathrm{kgf} / \mathrm{cm}^{2}$. Chemical generation of oxygen from various substances is not efficient and is currently good only for laboratories. Oxygen is electrolytically generated for industrial needs as well (in particular, where electric power is cheap).

Oxygen is massively used in medicine and recreation. It is likely that cardiovascular and other diseases are caused by the lack of oxygen in everyday life. In other words, because of the lack of oxygen people fall ill and significant sums pay for oxygen treatment. However, those who pollute the atmosphere only get richer; medical workers and producers of oxygen for therapeutic purposes also profit from human diseases.

Moreover, oxygen is used in agriculture, in the fishing industry (for fish, shrimp and mussel farming) and to increase the flame temperature in incinerators.

Therefore, insofar as today technically pure oxygen in industry is generated in two ways - from air (through deep freezing in special air separation installations) and from water (through electrolysis), the abovementioned cost of oxygen production is acceptable for calculations. Oxygen production from air is more cost efficient: $0.5-1.6 \mathrm{kWh}$ of electrical power is needed to generate $1 \mathrm{~m}^{3}$ of oxygen. $10-21 \mathrm{kWh}$ is necessary to obtain $1 \mathrm{~m}^{3}$ of oxygen through water electrolysis.

Nowadays there are no efficient installations to produce oxygen or nitrogen. If we take the UAH $1.76 / \mathrm{m}^{3}$ cost of oxygen production by generators, the nitrogen cost will be UAH $2.63 / \mathrm{m}^{3}$. We use the lowest cost of oxygen production for calculations UAH $1.76 / \mathrm{m}^{3}$ and UAH $43.64 / \mathrm{m}^{3}$ (cost of oxygen or nitrogen in tanks is not considered so far); nitrogen cost - UAH $2.63 / \mathrm{m}^{3}$ and UAH $43.64 / \mathrm{m}^{3}$ (depending on the way oxygen and nitrogen are produced). Then the cost of $4.2 \mathrm{~m}^{3}$ of oxygen will be from UAH 7.43 to 183.26 . The cost of $15.6 \mathrm{~m}^{3}$ of nitrogen will be from UAH 41.18 to 680.74 . At these rates, the air will cost from UAH 48.6 to 864.0 without the cost of generators, which cost hundreds of thousands of dollars in industrial production. Therefore, for dilution of $1 \mathrm{mg}$ of $\mathrm{SO}_{2}$ an enterprise has to pay from UAH 48.6 to 864.0 for 
exploitation of air. Nature provides the air free of charge; an economic entity saves money in such a way and receives the rent - the ecological one.

Calculation sample.

1. Given the cost of oxygen and nitrogen production - major air components - UAH $1.76 / \mathrm{m}^{3}$ and UAH $2.63 / \mathrm{m}^{3}$ :

- cost of $19.8 \mathrm{~m}^{3}$ of air for dilution of $1 \mathrm{mg}$ of $\mathrm{SO}_{2}$ with CL $0.05 \mathrm{mg} / \mathrm{m}^{3}$ - UAH 48.6 (cost of oxygen for dilution of $1 \mathrm{mg}$ of $\mathrm{SO}_{2}$ with $4.2 \mathrm{~m}^{3}$ volume - UAH 7.43; cost of $15.6 \mathrm{~m}^{3}$ of nitrogen UAH 41.18);

- cost of $0.001683 \mathrm{~m}^{3}$ of air for dilution of $1 \mathrm{mg}$ of $\mathrm{CO}_{2}$ with $589 \mathrm{mg} / \mathrm{m}^{3} \mathrm{CO}_{2}$ concentration in air - UAH 0.00411723 (cost of $0.000357 \mathrm{~m}^{3}$ of oxygen - UAH 0.000626535 ; cost of $0.001326 \mathrm{~m}^{3}$ of nitrogen - UAH 0.003490695);

with production cost of oxygen UAH $1.76 / \mathrm{m}^{3}$, the cost of $1 \mathrm{t}$ of oxygen - UAH 1228.13145 (i.e. 3.3 times more than oxygen quotas suggested by V.M. Boldyrev by- UAH $372.6 / \mathrm{t}$ $(\$ 46.58 / \mathrm{t})$ ).

2. Given the cost of oxygen and nitrogen production - major air components - UAH $43.64 / \mathrm{m}^{3}$ (depending on the way oxygen and nitrogen are produced):

- cost of $19.8 \mathrm{~m}^{3}$ of air for dilution of $1 \mathrm{mg}$ of $\mathrm{SO}_{2}$ with CL $0.05 \mathrm{mg} / \mathrm{m}^{3}$ - UAH 864.0;

- cost of $0.001683 \mathrm{~m}^{3}$ of air for dilution of $1 \mathrm{mg}$ of $\mathrm{CO}_{2}$ with $589 \mathrm{mg} / \mathrm{m}^{3} \mathrm{CO}_{2}$ concentration in air - UAH 0.07344401625;

with production cost of oxygen UAH $43.64 / \mathrm{m}^{3}$, the cost of $1 \mathrm{t}$ of oxygen - UAH 30537.9635625/t (i.e. 82 times more than oxygen quotas suggested by V.M. Boldyrev by- UAH $372.6 / \mathrm{t}(\$ 46.58 / \mathrm{t}))$.

For comparison. As of July 2013.

1. Given the cost of oxygen and nitrogen production - major air components - UAH $0.52 / \mathrm{m}^{3}$ and UAH $0.78 / \mathrm{m}^{3}$ :

- cost of $19.8 \mathrm{~m}^{3}$ of air for dilution of $1 \mathrm{mg}$ of $\mathrm{SO}_{2}$ with CL $0.05 \mathrm{mg} / \mathrm{m}^{3}$ - UAH 14.4 (cost of oxygen for dilution of $1 \mathrm{mg}$ of $\mathrm{SO}_{2}$ with $4.2 \mathrm{~m}^{3}$ volume - UAH 2.2; cost of $15.6 \mathrm{~m}^{3}$ of nitrogen UAH 12.2);

- cost of $0.001683 \mathrm{~m}^{3}$ of air for dilution of $1 \mathrm{mg}$ of $\mathrm{CO}_{2}$ with $589 \mathrm{mg} / \mathrm{m}^{3} \mathrm{CO}_{2}$ concentration in air - UAH 0.00121992 (cost of $0.000357 \mathrm{~m}^{3}$ of oxygen - UAH 0.00018564 ; cost of $0.001326 \mathrm{~m}^{3}$ of nitrogen - UAH 0.00103428).

With cost of oxygen production UAH $0.52 / \mathrm{m}^{3}$, the cost of $1 \mathrm{t}$ of oxygen - UAH 363.8908 (i.e. 3.3 times more than suggested by V.M. Boldyrev by oxygen quotas - UAH 110.4/t (\$ $13.8 / \mathrm{t}))$.
2. Given the cost of oxygen and nitrogen production - major air components - UAH $12.93 / \mathrm{m}^{3}$ (depending on the way oxygen and nitrogen are produced):

- cost of $19.8 \mathrm{~m}^{3}$ of air for dilution of $1 \mathrm{mg}$ of $\mathrm{SO}_{2}$ with CL $0.05 \mathrm{mg} / \mathrm{m}^{3}$ - UAH 256;

- cost of $0.001683 \mathrm{~m}^{3}$ of air for dilution of $1 \mathrm{mg}$ of $\mathrm{CO}_{2}$ with $589 \mathrm{mg} / \mathrm{m}^{3} \mathrm{CO}_{2}$ concentration in air - UAH 0.02176119;

with production cost of oxygen UAH $12.93 / \mathrm{m}^{3}$, the cost of $1 \mathrm{t}$ of oxygen - UAH 9048.2855/t (i.e. 82 times more than suggested by V.M. Boldyrev by oxygen quotas - UAH 110.4/t (\$ $13.8 / \mathrm{t}))$.

Although nowadays it is reasonable to apply the ecosystem approach to evaluate losses from atmospheric air pollution, we still should not abandon the normative approach, in particular the application of CL. Indeed, the amount of compensation of damage to nature depends on how atmospheric air is purified. If there is no criterion, how do we understand whether the air is purified or not? If cleaning is only done on a small scale, then it will be unknown whether the air is suitable for respiration by humans. Another matter is that the CL rates should be reviewed.

Methodological approaches to calculation of prevented economic losses from the loss of the air ecosystem's assimilative capacity, distant in time and of indirect nature.

The document "Temporary Methods of Determining Prevention of Ecological Losses " (State Committee of Russian Federation on Environmental Protection, 1999) provides the following definition: "2.10. Prevented economic loss from atmospheric pollution is the evaluation in monetary terms of possible negative consequences from pollution, avoided in a certain period of time due to operation of environmental authorities, complex of activities undertaken for air protection and implementation of nature protection programs".

In order to purify atmospheric air it is reasonable to plant trees and undertake other nature protection activities. According to State Agency of Forest Resources of Ukraine as of September 2016, at least UAH 7-8.0 thous. are needed to plant (manually) 1ha of pine forest and to preserve it. However, one has to wait 80-90 years before logging (up to 200 years for oak forests), constantly spending significant funds for conserving the forest and protecting it from pests or adverse weather.

Millennium Ecosystem Assessment finds that in the majority of countries the market values of ecosystems related to production of timber and firewood are less than $1 / 3$ of their overall economic cost, including the non-market values, such as 
carbon sequestration, water protection functions and recreation.

Preventive measures are costly, but they contribute to purification of atmospheric air. In addition to installation of filters and modernization of production, it is also reasonable to plant trees. Indeed, Lakyda I.P. (Lakyda, 2011) calculates that oak and pine trees have the strongest oxygen production capacity (6.7t/ha and 4.8-5.9t/ha accordingly). Each year 1 ha of 20-yeas old pine forests absorbs $9.35 \mathrm{t}$ of carbon dioxide and generates $7.25 \mathrm{t}$ of oxygen and one ha of 60-year old pines absorbs $14.4 \mathrm{t}$ of carbon dioxide and generates $10.9 \mathrm{t}$ of oxygen. In their turn, 40-year old oak forests absorb 18t of carbon dioxide and generate $13.9 \mathrm{t}$ of oxygen each year. Moreover, artificially developed forests have a lower level of oxygen production. I.P. Lakyda has determined that oxygen production of urban modal artificial pine forests in Kyiv ranges from 38.2 (age - 10 years) to $2,224.6$ (age - 140 years) t/ha by general productivity.

To evaluate the prevented economic losses from atmospheric air pollution, it is reasonable to use the current Methods of Calculation of Vegetation Replacement Cost (2009) (Ministry of Housing of Ukraine, 2009):

The replacement of the cost of trees and shrubs consists of the cost of their development (planting) and maintenance in previous years, taking into account the characteristics that define their value:

$$
\mathrm{C}_{\mathrm{r}}=C_{d e v}+C_{k}
$$
shrubs;

where: $\mathrm{C}_{\mathrm{r}}-$ replacement cost of trees and

$C_{d e v}-$ cost of development (planting) of trees and shrubs (the complex of work on their development and maintenance in the engraftment period);

$C_{k}$ - cost of preserving trees and shrubs in previous years, taking into account the characteristics that define their value.

Indeed, in our calculations we use the most efficient method used abroad - the method of replacement costs.

Conclusions. Therefore, the institutional environment that includes regulative and organizational provision of evaluation of economic losses from pollution of atmospheric air is partially coordinated with international formal rules and organizational structures that evaluate economic losses. However, timely transformation based on the ecosystem approach and EU directives is necessary for further efficient evaluation of maintenance.

Definitions indicated in Article 2 of the Directive 2008/50/EC of the European Parliament and of the Council of 21 May 2008 on Ambient Air Quality and Cleaner Air for Europe can be applied for methodological approaches to evaluation of economic losses from partial loss of the air ecosystem's assimilative capacity. However, the ecosystem approach is not apparent in the Directive.

Regarding the development of methodological approaches to evaluation of economic losses from atmospheric air pollution based on the ecosystem approach, it is reasonable to use correlation coefficients of ecosystems' assimilative properties in the new methodology and to improve the current Methodology of Calculation of Compensation for Losses Inflicted on the Nature of the Nation Due to Excessive Emissions of Pollutants into the Atmospheric Air to differentiate the charge of compensation of economic losses from atmospheric air pollution.

In order to define the volumes of economic losses from partial deprivation of the air ecosystem's assimilative capacity, it is necessary to reveal the harmful impact of dangerous chemical substances on human health, flora or fauna and ecosystems. The table "Dangerous chemical substances - air pollutants with harmful impact on human health, flora or fauna and ecosystems" or "Emissions of chemical and radioactive substances by TPPs into the atmospheric air and their possible consequences for public health" should be developed.

Therefore, development of the authors' methodological approaches to defining the amounts of economic losses from partial loss of the air ecosystem's assimilative capacity can become the foundation of a new methodology in Ukraine. Further scientific research should forward the development of methodological approaches to evaluation of the operation cost of the air ecosystem's assimilative capacity, although based on other methods, like the hedonic one, or in the context of marginal utility theory centered around the defining of subjective economic value of benefits for a concrete consumer.

\section{References}

Balatsky, O.F., 2007. Antologiya ekonomiki chistoy sredy [Anthology of clean environment economics]. Sumy: IUD "University Book" (in Russian).

Boldyrev, V. 2001. Atmosfernym kislorodom - po globalizatsii i kreditoram. Znachimyy faktor geopolitiki, natsional'noy bezopasnosti i 
pogasheniya dolgov Rossii [Atmospheric oxygen on globalization and creditors. Significant factor of Russia's geopolitics, national security and debts repayment]. Promyshlennyye vedomosti: ekspertnaya obshcherossiyskaya gazeta Industrial Records: Expert Pan-Russian Newspaper,5-6 (16-17) http://www.promved.ru/mart_2001_01.shtml (in Russian).

Cabinet of Ministers of Ukraine (2001). Pro zatverdzhennya Poryadku rozroblennya ta zatverdzhennya normatyviv hranychnodopustymykh vykydiv zabrudnyuyuchykh rechovyn iz statsionarnykh dzherel [On approval of the procedure for the development and approval of the rates of maximum permissible emission of pollutants from stationary sources]. 2001, December 28, 1780. http://zakon.rada.gov.ua/laws/show/1780-2001-п

Cryogen (2016). Pod Tsyurikhom postroyat pervyy na planete zavod po ochistke vozdukha ot uglekislogo gaza [The first ever plant to clean the air from carbon dioxide to be constructed near Zurich].

:http://cryogen.com.ua/2016/\%d0\%bf\%d0\%be\%d $0 \%$ b4\%d1\%86\%d1\%8e\%d1\%80\%d0\%b8\%d1\%8 $5 \%$ d0\%be\%d0\%bc\%d0\%bf\%d0\%be\%d1\%81\%d1 $\% 82 \%$ d $1 \% 80 \%$ d0\%be $\%$ d1 $\% 8 f \%$ d1 $\% 82 \%$ d0\%bf $\%$ d0\%b5\%d1\%80\%d0\%b2\%d1\%8b\%d0\%b9\%d0 $\%$ bd $\%$ d0\%b0\%d0\%bf\%d0\%bb\%d0\%b0\%d0\%bd $\% \mathrm{~d} 0 \% \mathrm{~b} 5 \% \mathrm{~d} 1 \% 82 /$ (in Ukrainian).

Davydova, A. (2018). Za uglerod vse chashche prosyat tsenu. No dlya vypolneniya tseley Parizhskogo soglasheniya etogo ne khvatayet [For carbon, they are increasingly imposing a price. But this is not enough to fulfill the goals of the Paris Agreement]. 2018, May 28, Newspaper "Kommersant", https://www.kommersant.ru/doc/3642476

Directive of European Parliament and Council (2008). Pro yakist atmosfernoho povitrya ta chystishe povitrya dlya Yevropy [Ambient Air Quality and Cleaner Air for Europe: 2008/50/EU]. Order, adopted on 2008, May 21, 2008 on Directive [Internet resource]. - Available from: http://zakon2.rada.gov.ua/laws/show/994_950 (in Ukrainian).

Emerton, L., \& Kekulandala, L.D.C.B. (2003). Assessment of the Economic Value of Muthurajawela Wetland. Occasional Papers of IUCN, No. 4. Colombo, Sri Lanka: International Union for Conservation of Nature and Natural Resources, Regional Environmental Economics Programme (IUCN Asia).

Kvashyn, I. M., Hurin, I.I., (2008). K voprosu o normirovanii vozdukhoobmena po soderzhaniyu $\mathrm{CO} 2 \mathrm{v}$ naruzhnom i vnutrennem vozdukhe [On the issue of oxygen exchange regulation in terms of co 2 content in external and internal oxygen]. Abok http://www.abok.ru/for_spec/articles.php?nid=404 6 (in Russian).
Lakyda, I. P., (2011). [Kysneproduktyvnist modalnykh shtuchnykh sosnyakiv miskykh lisiv mista Kyeva [Oxygen Productiveness of Modal Artificial Urban Pine Forests in Kyiv] http://www.nbuv.gov.ua/portal/chem_biol/nvnau_l ds/2011_164_3/11lip.pdf (in Ukrainian).

Lobasov, O. P., Suhina, O. M., \& Zhyshko, M. I. (2013). Rozvytok metodolohichnykh pidkhodiv do ekonomichnoyi otsinky mineral'no-syrovynnykh resursiv [Development of methodological approaches to the economic evaluation of mineral resources]. Ekonomika Ukrayiny - Economy of Ukraine, 2, 67-80. (in Ukrainian).

Law of Ukraine (2010). Pro Osnovni zasady (stratehiyu) derzhavnoyi ekolohichnoyi polityky Ukrayiny na period do 2020 roku [On Major Foundations (Strategy) of 2020 State Ecological Policy of Ukraine]. 2010, December 21, 2818-VI. http://zakon0.rada.gov.ua/laws/show/2818-17 (in Ukrainian).

Maksymiv, Yu.V., Popadynets, N.M., (2016). Rozvytok vnutrishnoho rynku tverdoho biopalyva Ukrayiny $\mathrm{v}$ suchasnykh umovakh [Development of the market of solid biofuel in Ukraine under current conditions] Ekonomichnyy chasopys-XXI Economic Annals-XXI, 159(5-6), 93-96. (in Ukrainian).

Matyukha, V. V. (2016). Metodologicheskiy podkhod k otsenke ekonomicheskoy effektivnosti razrabotki mestorozhdeniy na osnove opredeleniya normy diskonta [Methodological approach to the estimation of the economic efficiency of field development on the basis of determination of discount rate]. Gornyy zhurnal - Mountain Journal, 1, 59-61. (in Russian).

Mayer, L. A., Boufadel, M. C., Brenner, J., \& et al. (2012). Approaches for Ecosystem Services Valuation for the Gulf of Mexico After the Deepwater Horizon Oil Spill: Interim Report (National Research Council). Washington, DC: The National Academies Press. https://www.nap.edu/read/13141/chapter/5

Melnyk, L. H. (Ed), Karintseva, O. I. (2004). Methods of estimation of ecological losses [Methods of Ecological Losses' Evaluation]. Sumy : VTD "Universytetska knyha" (in Ukrainian).

Meng, G., Sarath, K. Gregory R. \& et al. (2015). Health impacts and economic losses assessment of the 2013 severe haze event in Beijing area. Science of The Total Environment, 511, 553561.doi.org/10.1016/j.scitotenv.2015.01.005.

Ministry of Healthcare of Ukraine (1996). Pro zatverdzhennya Derzhavnykh sanitarnykh pravyl planuvannya ta zabudovy naselenykh punktiv [On Approval of State Sanitary Regulations of Planning and Development of Settlements]. Order of the 1996, June 19, 173. http://zakon.rada.gov.ua/rada/show/z0379-96 (in Ukrainian).

Ministry of Healthcare of Ukraine (1997). Derzhavni sanitarni pravyla okhorony atmosfernoho povitrya naselenykh mists (vid zabrudnennya khimichnymy 
ta biolohichnymy rechovynamy [State sanitary regulations concerning the protection of settlements' atmospheric air (from pollution with chemical and biological substances)]. Order of 1997, July 9,201 http://zakon.rada.gov.ua/rada/show/v0201282-97 (in Ukrainian).

Ministry of Environmental Protection of Ukraine (2008). Pro zatverdzhennya Metodyky rozrakhunku rozmiriv vidshkoduvannya zbytkiv, yaki zapodiyani derzhavi v rezultati nadnormatyvnykh vykydiv zabrudnyuyuchykh rechovyn $\mathrm{v}$ atmosferne povitrya [On adoption of the methodology of calculation of losses sustained by the state due to excessive emissions of pollutants into the atmospheric air] Order, adopted on 2008, December 10 639. http://zakon0.rada.gov.ua/laws/show/z0048-09 (in Ukrainian).

Ministry of Environmental Protection of Ukraine (2006). Pro zatverdzhennya normatyviv hranychnodopustymykh vykydiv zabrudnyuyuchykh rechovyn iz statsionarnykh dzherel [On approving of the rates of maximum permissible emission of pollutants from stationary sources] Order, adopted on 2006, June 27, 309. http://zakon2.rada.gov.ua/laws/show/z0912-06 (in Ukrainian).

Ministry of Housing of Ukraine (2009). Pro zatverdzhennya Metodyky vyznachennya vidnovnoyi vartosti zelenykh nasadzhen [On adoption of the methodology of calculation of replacement costs of green plantings]. Order of 2009, May 12, 127. http://zakon2.rada.gov.ua/laws/show/z0549-09 (in Ukrainian).
Razovskyi, Yu. V., Suhina, O. M. (2017) Klassifikatsiya mineral'no-syr'yevogo i ekologicheskogo kapitala po istochniku formirovaniya [Classification of Mineral-Raw Material and Ecological Capital by the Source of Forming]. Gornyy zhurnal Mountain Journal, 10, 22-25. (in Russian).

State Committee of Russian Federation on Environmental Protection (1999). Vremennaya metodika opredeleniya predotvrashchennogo ekologicheskogo ushcherba [Temporary methodology of calculation of prevented ecological damage]. Order of the 1999, March 9. http://meganorm.ru/Index2/1/4294849/429484956 9.htm (in Russian).

Suhina, O., Ulytskyi, O., Razovskiy, Y., Serhii, P., (2018). Estimation of Damage from Atmospheric Air Pollution by Determination of Cost of Oxygen Production through the Installation of Artificial Photosynthesis. Fundamental and Applied Research: Collection of scientific articles. Melbourne (Australia): Dingo Publishing, 47-51.

Tagaeva, T. O., Gilmundinov, V. M., \& Kazantseva, L. K. (2015). Ekonomicheskie metody regulirovaniya kachestva okruzhayushchey sredy v Rossii [Economic methods for regulating the quality of the environment in Russia]. Mir novoy ekonomiki - The World of a New Economy, 4, 48-61. (in Russian).

Yazhlev, I. K. (2009). O sostoyanii metodicheskogo obespecheniya otsenki ushcherba prirodnoi srede v Rossiiskoi Federatsii i za rubezhom [The study of the state of the methodological support of environmental damage evaluation in the Russian Federation and abroad]. Teoriya i praktika sudebnoy ekspertizy - Theory and Practice of Forensic Science, 3 (15), 194-221 (in Russian). 